\title{
Improving Quality of Wonderful Pomegranate by Using Bagging and Different Agrochemical Treatments
}

\author{
Abdel-Sattar, M. ${ }^{*}$, A. M. Eissa, S. M. El-shazly and A. S. Alabd \\ Pomology Department, Faculty of Agriculture (El-Shatby), Alexandria Univ., Egypt. \\ *Corresponding author: M. Abdel-Sattar Fax: +2035922780, Email: mahmoud.hassan @alexu.edu.eg
}

\begin{abstract}
The present study was carried out during the two successive seasons of 2014 and 2015 on five years old Wonderful pomegranate cultivar (Punica granatum, L) in order to investigate the effect of fruit bagging, spraying with lime milk, super nano, $\mathrm{CaCO}_{3}$, vitamin $\mathrm{C}$ and kaolin, as well as, nitrogen and potassium fertilization on the fruit quality especially the incidence of sunburn. The obtained results showed that all treatments significantly affected fruit sunburn percentage and number of sunburned fruits, especially bagging, super nano and kaolin sprays. A significant decrease in the sunburn severity occurred with the bagging and super nano sprays treatments. All different treatments increased fruit TSS and vitamin C. Spraying super nano on the fruit was the best in increasing TSS/acidity ratio. Spraying lime milk or super nano on the tree and were the best in increasing fruit anthocyanin content.
\end{abstract}

Keywords: pomegranate, Bagging, Lime milk, Super nano, CaCO3, Vitamin C, Kaolin, Fertilization, Quality.

\section{INTRODUCTION}

The pomegranate (Punica granatum L.) which belongs to the family Punicaceae, is one of the fruit species mentioned in the Holy Quran. It is mainly grown in in the Mediterranean region and central Asian. In Egypt, the cultivated area nowadays is rapidly increasing especially with the cultivar Wonderful. The total cultivated area is about 26351 feddan, with a fruiting area of about 9746 feddan that produces about 89035 tons (Agriculture statistics, 2012). The acceptability of a pomegranate to the consumer and processor depends on a combination of several quality attributes that are related to physico-chemical and mechanical properties such as attractive skin, small seeds in the aril, skin color, smoothness, sugar, vitamin C, anthocyanin contents and free of cracking, as well as fruit sunburn incidence which cause dark-brown to black discoloration of the affected skin area (AlSaid et al., 2009).

Additionally, some fruit tree species might be more resistant than others to the direct sunlight injuries by having a canopy with bigger leaf surface area that provides better shading over the fruits. For pomegranate, this is not available and means of fruit protecting from sunlight is recently being paid attention. For example, shades or screens could be used to cover the trees and protect fruits from the direct exposure to sunlight (Melgarejo et al., 2004). Also, fruit bagging, a physical protection technique commonly applied to many fruit species to improve appearance of the fruit by promoting fruit coloration and reducing the incidence of fruit sunburn ( $\mathrm{Xu}$ et al., 2010). Lime milk is a mixture of quicklime, plastic and water. It covers fruits with a thin white layer that reflects sunlight. Calcium carbonate reflects harmful ultraviolet (UV) and infrared (IR) radiation without blocking leaf stomata or impeding photosynthesis (Bedrech and Farag, 2015).In the meantime, ascorbic acid is considered an antioxidant that can catch free radicals in the plant tissues and provide adequate protection against the deleterious effects of activated oxygen species, thus increase the plant resistance to stress (Nicholas, 1996; Alscher et al., 1997). Kaolin has recently been utilized in the development of hydrophilic particle film technology. This technology uses chemically inert, non-toxic mineral particles to coat plant surfaces (Glenn et al., 1999). It allows the passage of beneficial radiation necessary for photosynthesis and reflects harmful radiation. It is sprayed onto trees foliage and fruit to form a thin crystalline layer that reflects sunlight. In the meanwhile, nitrogen and potassium fertilization could have a positive influence on the development of vegetative growth that provides proper fruit shading (Cuqel et al., 2011)

In accordance to the previously discussed, the present study was conducted in order to investigate the effect of fruit bagging, lime milk, $\mathrm{CaCO}_{3}$, vitamin $\mathrm{C}$, kaolin and super nano sprays, as well as nitrogen and potassium fertilization on fruit quality and chemical determinations of Wonderful pomegranate grown in a private orchard (El-Roda Company for Agricultural Development) at Banger region, El-Beheera governorate, Egypt. 


\section{MATERIALS AND METHODS \\ Plant Material and Experimental Design:}

The experiment was conducted during 20132014 and 2014-2015 growing seasons on five years old Wonderful pomegranate cultivar (Punica granatum, L). The trees were planted in sandy soil in a private orchard (El-Roda Company for Agricultural Development) located at $75 \mathrm{~km}$ Alexandria - Cairo desert road. Trees were planted at spacing of $2 \times 5$ meters and irrigated with drip irrigation system. Trees were fertilized with cattle manure at a rate of $8 \mathrm{Kg}$ per tree in November of both years. In the two successive years, nitrogen, phosphorus, potassium calcium and magnesium were added at a rate of $60,25,80,35$ and 20 units per feddan, respectively. All trees received the ordinary management practices usually applied in the pomegranate orchard, including irrigation and pest control.

For the present study, 45 trees were selected as uniform as possible in growth and vigor and were subjected to the following treatments with 5 replicates for each treatment and a single tree for each replicate (i.e. 9 treatments $\mathrm{x} 5$ replicates $=45$ trees) and treatments were arranged in a randomized complete block design (RCBD) according to Gomez and Gomez (1984):

$\mathrm{T}_{1}$ - Water spray (control)

$\mathrm{T}_{2}$ - Bagging

$\mathrm{T}_{3}$ - Lime Milk

$\mathrm{T}_{4}-\mathrm{CaCO}_{3}$

$\mathrm{T}_{5}-$ Vitamin $\mathrm{C}$

$\mathrm{T}_{6}$ - Kaolin

$\mathrm{T}_{7^{-}}$Super nano fruit spray

$\mathrm{T}_{8}$ - Super nano canopy spray

$\mathrm{T}_{9}$ - Fertilization

The bagging and spraying treatments were applied when the fruits have reached three $\mathrm{cm}$ in diameter. Fruit bagging (paper bags $20 \times 30 \mathrm{~cm}$ ) and lime milk $(5 \mathrm{~kg}$ quicklime $+35 \mathrm{~kg}$ white plastic paint +20 Liter water per feddan) were applied frequently from the second week of June until the first week of August and bags were removed two weeks before the expected harvesting date. Fruit were sprayed with $3 \%$ calcium carbonate $\left(\mathrm{CaCO}_{3}\right)$, $3 \%$ kaolin (a soluble powder of aluminum silicate $\left(\mathrm{Al}_{2} \mathrm{Si}_{2} \mathrm{O}_{7}\right)$ mineral clay formulated for conventional spray) and $100 \mathrm{ppm}$ vitamin $\mathrm{C}$ four times at 15 days intervals from the second week of June to the first week of August, to keep powder film thickness on fruits steady. Super nano (a production of the Middle East Company for mining investment and consists of $96 \%$ aluminum silicate $\left(\mathrm{Al}_{2} \mathrm{Si}_{2} \mathrm{O}_{7}\right), 3.5 \%$ silicon dioxide and $0.5 \%$ mineral elements) was sprayed either on the fruit or on the tree canopy four times at 15 days intervals from the second week of June to the first week of August, the first application at $50 \mathrm{~g} /$ liter and the other three at $25 \mathrm{~g} /$ liter. Ammonium nitrate and potassium sulfate fertilizers were added in June and was more than the orchard program by $10 \%$.

\section{Measurements and Determinations}

In order to determine fruit physico-chemical properties, fruit samples from each replicate was randomly collected at the harvest date in the second week of October and directly transported to the laboratory of the Faculty of Agriculture, Alexandria University.

\section{Fruit physical properties}

In a fruit sample of five fruits from each replicate; fruit weight $(\mathrm{g})$, peel weight $(\mathrm{g})$, aril weight $(\mathrm{g})$, fruit length $(\mathrm{cm})$ and fruit diameter $(\mathrm{cm})$ were measured. Also fruit peel color (one measurement at one point on the equatorial region of each individual fruit) was assessed, using Minolita Chroma Meter CR-2000. The number of sunburned fruits was counted and estimated for each replicated a week before harvest and the percentage of sunburned fruits for each treatment was calculated. In addition, the discolored areas due to sunburn were measured using Computer Aided Design (CAD) technique according to Rico-Garcia et al. (2009). The severity of sunburn discoloration was estimated according to the sunburned area. This parameter assessment was based on five grades from one to five according to the sunburned area of the fruit peel as follow; $1=$ less than $10 \mathrm{~cm}^{2}, 2=10$ to $20 \mathrm{~cm}^{2}, 3=20$ to $30 \mathrm{~cm}^{2}, 4=30$ to $40 \mathrm{~cm}^{2}, 5=$ more than $40 \mathrm{~cm}^{2}$.

\section{Fruit chemical properties}

In another fruit sample of five fruits from each replicate fruit grains were squeezed and the obtained juice was used to determine the percentage of TSS by hand refractometer. Five $\mathrm{ml}$ from the obtained juice were used to determine the titratable acidity as $\mathrm{g}$ citric acid $/ 100 \mathrm{ml}$ juice according to Chen and Mellenthin (1981). Vitamin C was determined by titration with 2,6-dichlorophenolindophenol blue dye as $\mathrm{mg}$ ascorbic acid $/ 100 \mathrm{ml}$ juice according to the A.O.A.C (1995). Anthocyanin was determined by a $\mathrm{pH}$ differential method with two buffer systems according to Giusti et al. (1999).

\section{Statistical analysis}

All data were tested for treatments effects on analyzed parameters by one-way analysis of variance (ANOVA) technique. Treatments means were separated and compared using least significant difference (L.S.D) at 0.05 level of probability according to Steel and Torrie (1980). The statistical analysis was performed using SAS (Statistical Analysis System) version 9.13, (2008).

\section{RESULTS AND DISCUSSION}

\section{Fruit physical properties}

Data obtained in both seasons showed that fruit, peel and aril weight and fruit length and diameter were not significantly affected by any of the 
treatments in comparison with the water sprayed control (Table1).

These results partially goes on line with those previously reported by Brown et al. (2001) who found that spraying apple with kaolin did not affect fruit weight. In this respect, Melgarejo et al. (2004) mentioned that kaolin worked as an effective sunscreen while it gave non-significant influences on fruit diameter. Also, Hegazi et al. (2014) found that fruit diameter and fruit length were not affected by kaolin spray or bagging of "Manfaloty" pomegranate. On the other hand, significant increase in fruit weight, diameter and length of pomegranate by kaolin treatments was reported (Abd El-Rhman, 2010; Ehteshami et al., 2012; Samra and Shalan, 2013).

With regard to fruit color, results of both seasons presented in Table (2) showed that the $\mathrm{L}^{*}$ value was significantly lower than the control by lime milk treatment (in both seasons) and vitamin C and kaolin treatments in the second season, while, the $\mathrm{a}^{*}$ value increased by the lime milk and kaolin treatments in the first season and by vitamin $\mathrm{C}$ in both seasons. In addition, the lime milk, kaolin and super nano treatments resulted in higher $b^{*}$ value than the control. Data also showed that higher value of chroma than the control was obtained by vitamin $\mathrm{C}$ treatment in both seasons and by bagging and lime milk in the first season only.

Similarly, Yazici and Kaynak (2005) found that spraying kaolin increased the red color of pomegranate fruits. Also, Fan and Mattheis (1998) on apple, Chonhenchob et al. (2011) on mango and Hudina et al. (2012) on pear and Shen et al. (2014) on peach recorded high value of $\left(\mathrm{L}^{*}\right)$ and $\left(\mathrm{a}^{*}\right)$ by fruit bagging. The positive effect of kaolin on fruit color might be likely due to its effect in decreasing fruit temperature during the hottest hours of the day that is unfavorable for pigment synthesis (Pace et al., 2007).

Table 1: Effect of the different treatments on fruit physical properties of Wonderful pomegranate in 2014 and 2015 seasons.

\begin{tabular}{|c|c|c|c|c|c|c|c|c|c|c|}
\hline \multirow[b]{2}{*}{ Treatments } & \multicolumn{5}{|c|}{2014} & \multicolumn{5}{|c|}{2015} \\
\hline & $\begin{array}{r}\text { Fruit } \\
\text { weight } \\
\text { (g) } \\
\end{array}$ & $\begin{array}{r}\text { Peel } \\
\text { weight } \\
(\mathrm{g}) \\
\end{array}$ & $\begin{array}{r}\text { Aril } \\
\text { weight } \\
(\mathrm{g}) \\
\end{array}$ & $\begin{array}{l}\text { Fruit } \\
\text { length i } \\
(\mathrm{cm})\end{array}$ & $\begin{array}{r}\text { Fruit } \\
\text { ameter } \\
(\mathrm{cm}) \\
\end{array}$ & $\begin{array}{r}\text { Fruit } \\
\text { weight } \\
\text { (g) } \\
\end{array}$ & $\begin{array}{r}\text { Peel } \\
\text { weight } \\
(\mathrm{g}) \\
\end{array}$ & $\begin{array}{r}\text { Aril } \\
\text { weight } \\
(\mathrm{g}) \\
\end{array}$ & $\begin{array}{r}\text { Fruit } \\
\text { length } \\
(\mathrm{cm}) \\
\end{array}$ & $\begin{array}{r}\text { Fruit } \\
\text { diameter } \\
(\mathrm{cm}) \\
\end{array}$ \\
\hline Water spray (Control) & 324.76 & 122.09 & 202.66 & 7.89 & 8.82 & 350.92 & 203.64 & 150.84 & 8.07 & 9.12 \\
\hline Bagging & 324.75 & 122.09 & 202.66 & 7.71 & 8.76 & 368.61 & 204.87 & 165.17 & 8.11 & 9.04 \\
\hline Lime milk & 343.72 & 139.57 & 204.16 & 7.77 & 8.75 & 333.74 & 149.82 & 112.67 & 8.00 & 8.78 \\
\hline $\mathrm{CaCO}_{3}$ & 332.48 & 127.05 & 204.46 & 7.81 & 8.64 & 347.16 & 189.01 & 146.90 & 8.03 & 9.01 \\
\hline Ascorbic acid & 352.71 & 140.51 & 212.25 & 8.08 & 8.97 & 343.28 & 189.18 & 144.95 & 7.91 & 8.72 \\
\hline Kaolin & 362.37 & 139.17 & 223.20 & 7.97 & 8.84 & 377.35 & 211.52 & 148.21 & 8.05 & 9.20 \\
\hline Super nano fruit spray & 343.73 & 139.04 & 204.69 & 7.95 & 8.82 & 342.89 & 203.25 & 144.10 & 7.88 & 8.89 \\
\hline Super nano canopy spray & 344.07 & 134.02 & 202.36 & 7.89 & 8.75 & 330.90 & 190.76 & 149.46 & 8.05 & 8.95 \\
\hline Fertilization & 359.00 & 134.68 & 224.34 & 8.04 & 8.96 & 368.22 & 210.23 & 163.39 & 8.35 & 9.11 \\
\hline $\mathrm{LSD}_{0.05}$ & 47.32 & 30.65 & 22.47 & 0.33 & 0.43 & 46.78 & 22.33 & 33.06 & 0.41 & 0.40 \\
\hline
\end{tabular}

Means with the same letters for each column are not significantly different at 0.05 levels according to LSD method.

Table 2: Effect of the different treatments on fruit color of Wonderful pomegranate in 2014 and 2015 seasons.

\begin{tabular}{|c|c|c|c|c|c|c|c|c|}
\hline \multirow{3}{*}{ Treatments } & \multicolumn{8}{|c|}{ Fruit color } \\
\hline & \multicolumn{4}{|c|}{2014} & \multicolumn{4}{|c|}{2015} \\
\hline & $\mathbf{L}^{*}$ & a* & $\mathbf{b}^{*}$ & Chroma & $\mathbf{L}^{*}$ & $a^{*}$ & $\mathbf{b}^{*}$ & Chroma \\
\hline Water spray (Control) & 56.87 & 48.12 & 24.42 & 54.02 & 59.05 & 41.93 & 25.76 & 49.44 \\
\hline Bagging & 55.45 & 51.77 & 24.85 & 57.44 & 62.46 & 40.39 & 26.11 & 48.22 \\
\hline Lime milk & 51.40 & 53.35 & 21.62 & 57.58 & 51.46 & 43.85 & 23.52 & 50.05 \\
\hline $\mathrm{CaCO}_{3}$ & 56.47 & 48.97 & 23.18 & 54.37 & 58.82 & 43.29 & 24.40 & 49.93 \\
\hline Ascorbic acid & 54.49 & 52.54 & 24.28 & 57.85 & 51.71 & 49.11 & 23.23 & 54.38 \\
\hline Kaolin & 54.53 & 51.42 & 21.95 & 55.92 & 52.43 & 47.01 & 21.25 & 51.60 \\
\hline Super nano fruit spray & 53.49 & 50.40 & 19.19 & 53.96 & 58.32 & 41.83 & 21.79 & 47.35 \\
\hline Super nano canopy spray & 56.71 & 49.64 & 23.98 & 55.15 & 58.55 & 39.13 & 22.80 & 45.33 \\
\hline Fertilization & 57.52 & 47.80 & 22.59 & 52.94 & 59.47 & 43.93 & 25.20 & 50.77 \\
\hline $\mathrm{LSD}_{0.05}$ & 4.61 & 3.12 & 2.53 & 2.62 & 5.81 & 6.91 & 2.94 & 4.95 \\
\hline
\end{tabular}

Means with the same letters for each column are not significantly different at 0.05 levels according to LSD method. 
As for the percentage of the sunburned fruits, all treatments reduced the percentage of sunburned fruits, except ascorbic acid treatment in the second season when compared with the control (Table 3). Fruit bagging resulted in the lowest percent of sunburned fruits followed by the super nano sprays as compared with all other treatments.

Concerning the severity of sunburn, fruit bagging in general was the most effective treatment in decreasing sunburn severity especially a severity category of $30-40 \mathrm{~cm}^{2}$ and more. The kaolin and Super nano sprays also indicated similar results (Table 3).

These results are confirmed by those reported by Melgarejo et al. (2004), Ehteshami et al. (2012), Samra and Shalan (2013) and Hegazi et al. (2014) who stated that spraying kaolin to pomegranate trees significantly reduced fruit sunburn damage. Similarly, Wunsche et al. (2004) stated that spraying apple trees with kaolin reduced the percentage of sunburned fruits and he added that, kaolin reduces fruit surface temperature by increasing the reflection of visible and ultraviolet light. Also, Hegazi et al. (2014) and Ghorbani et al. (2015) found that bagging of pomegranate fruit reduced sunburn damage. Additionally, a significant reduction in fruit sunburn damage by spraying $\mathrm{CaCO} 3$ was reported by Weerakkody et al. (2009) on pomegranate. Reducing sunburn damage by bagging and kaolin may be attributed to their role in reflecting radiation, especially UV wavelengths which reach the fruit surface (Ergun, 2012). Further, super nano, and lime milk are considered white coating that reflect sun rays and reduce the sunburn damages. In the meantime, nitrogen and potassium fertilization might have enhanced the tree vegetative growth, and thus increase tree canopy which would have positive influence in offering better protection for the fruits from strong solar radiation and high temperature as previously mentioned by Melgarejo et al. (2004).

Table 3: Effect of the different treatments on the percentage of sunburned fruits and sunburn severity of Wonderful pomegranate in 2014 and 2015 seasons.

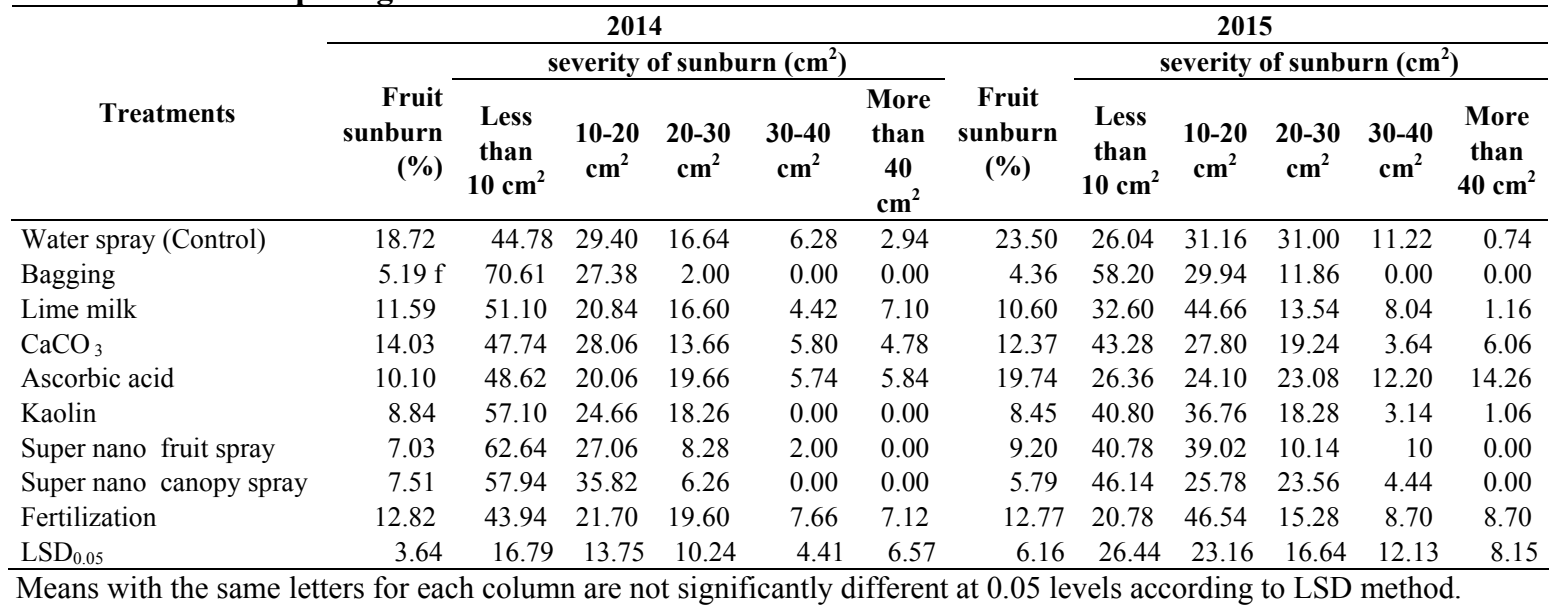


Table 4: Effect of the different treatments on chemical properties of Wonderful pomegranate in 2014 and 2015 seasons.

\begin{tabular}{|c|c|c|c|c|c|c|c|c|c|c|}
\hline \multirow[t]{2}{*}{ Treatments } & \multicolumn{2}{|c|}{ TSS (\%) } & \multicolumn{2}{|c|}{$\begin{array}{c}\text { Acidity } \\
(\%)\end{array}$} & \multicolumn{2}{|c|}{$\begin{array}{c}\text { TSS / acidity } \\
\text { ratio } \\
\end{array}$} & \multicolumn{2}{|c|}{$\begin{array}{l}\text { Vitamin C } \\
\mathrm{mg} / 100 \mathrm{ml}\end{array}$} & \multicolumn{2}{|c|}{$\begin{array}{c}\text { Anthocyanin } \\
\text { mg/100ml }\end{array}$} \\
\hline & 2014 & 2015 & 2014 & 2015 & 2014 & 2015 & 2014 & 2015 & 2014 & 2015 \\
\hline Water spray (Control) & 15.50 & 15.34 & 1.13 & 0.93 & 14.08 & 16.40 & 11.62 & 11.26 & 18.85 & 19.44 \\
\hline Fruit bagging & 16.34 & 16.16 & 1.08 & 0.93 & 15.24 & 17.29 & 16.85 & 20.37 & 24.75 & 25.79 \\
\hline Lime Milk & 16.66 & 16.53 & 1.02 & 0.98 & 16.46 & 16.80 & 14.31 & 21.00 & 35.31 & 34.07 \\
\hline $\mathrm{CaCo}_{3} 3 \%$ & 17.36 & 16.11 & 1.27 & 0.91 & 13.76 & 17.95 & 15.55 & 14.45 & 19.77 & 17.96 \\
\hline Vitamin C (100 ppm). & 16.58 & 16.98 & 1.16 & 1.06 & 14.52 & 16.01 & 15.60 & 20.79 & 23.73 & 22.29 \\
\hline Kaolin 3\% & 16.32 & 15.92 & 1.02 & 0.95 & 16.48 & 17.11 & 13.40 & 17.44 & 29.70 & 30.48 \\
\hline Super nano sprayed fruits only & 17.02 & 16.83 & 0.98 & 0.88 & 17.82 & 19.24 & 13.57 & 13.47 & 32.18 & 31.84 \\
\hline Super nano sprayed on the canopy & 17.28 & 16.70 & 1.28 & 0.94 & 13.56 & 17.84 & 17.57 & 18.20 & 36.41 & 34.21 \\
\hline Fertilization & 16.46 & 16.27 & 0.96 & 0.87 & 17.10 & 18.86 & 14.67 & 19.03 & 20.27 & 19.38 \\
\hline $\mathrm{LSD}_{0.05}$ & 0.59 & 0.55 & 0.19 & 0.13 & 2.93 & 2.78 & 1.70 & 2.43 & 4.80 & 3.81 \\
\hline
\end{tabular}

Means with the same letters for each column are not significantly different at 0.05 levels according to LSD method.

\section{CONCLUSION}

From the present results, it could be concluded that bagging and spraying Super nano either on the fruits or on the tree were considered the best and effective treatments in decreasing fruit sunburn percentage, and severity of sunburn, as well as it increased fruit TSS and vitamin C content.

\section{REFERENCES}

Abd EL-Rhman, I. E. (2010). Physiological studies on cracking phenomena of pomegranates. $J$. of Appl. Res., 6 (6): 696-703.

Agricultural Statistics (2012). Ministry of Agriculture, Summer and Nile Crops, Sector of Economic Affairs, Egypt.

Al-Said, F.A.; L.U. Opara and R.A. Al-Yahyai (2009). 'Physico-chemical and textural quality attributes of pomegranate cultivars (Punica granatum L.) grown in the Sultanate of Oman, J. Food Eng. 90:129-134

Alscher, R.G.; J.L. Donahne and C.L. Cromer (1997). Reactive oxygen species and antioxidants relationships in green cells. Physiol. Plant 100: 224-233.

A.O.A.C. (1995). Official Methods of Analysis of the Association of Official Analytical Chemistry. 16th Edn., AOAC International, Washington, USA., Pages: 1141.

Bedrech, S.A. and S.Gh. Farag (2015). Usage of some sunscreens to protect the Thompson Seedless and Crimson Seedless grapevines growing in hot climates from sunburn. Nature and Sci., 13 (12).

Brown, D.; L. Schimanski and D. Jennings (2001). Kaolin for pest control and improved fruit quality of apples. Sci. Hort., 1-10.

Chen, P.M. and W.M. Mellenthin (1981). Effects of harvest date on ripening capacity and postharvest life of 'd'Anjou' pears. J. Amer. Soc. Hort. Sci., 106: 38-42.
Chonhenchob, V.; D. Kamhangwong; J. Kruenate; K. Khongrat; N. Tangchantra; U. Wichai and S.P. Singh (2011). Preharvest bagging with wavelength-selective materials enhances development and quality of mango (Mangifera indica L.) cv. 'Nam Dok Mai' \#4. J. Sci. Food Agri., 91: 664-671.

Cuqel, F.L.; A.C.V. Motta;I. Tutida and L.L.M. D. Mio (2011). Nitrogen and potassium fertilization affecting the plum postharvest quality. Rev. Bras. Frutic., Jabotical-SP, Vol. Especial, E.328-336.

Ehteshami, S.; H. Sarikhani and A. Ershadi (2012). Effect of application of kaolin and gibberellins on some qualitative traits and reducing of sunburn in pomegranate $\mathrm{cv}$. Rabab Neiriz. Plant Prod. Tech., 11(1): 1524. (In Farsi)

Ergun, M. (2012). Postharvest quality of Galaxy apple fruit in response to kaolin-based particle film application. J. Agric. Tech., 14: 599-607.

Fan, X. and J.P. Mattheis (1998). Bagging "Fuji" apples during fruit development affects color development and storage quality. Hort. Sci., 33, 1235-1238.

Fayed, T.A. (2010). Effect of compost tea and some antioxidant application on leaf chemical constituents, yield and fruit quality of pomegranate. World J. Agric. Sci., 6 (4): 402-411.

Ghorbani, M.; G.R. Dabbagh; S. Yousefi; S. Khademi and M. Taki (2015). The effect of application of different kinds of covers on the sunburn and internal qualities of pomegranate in Iran. Biological Fourm - An International Journal, 7(1): 64-68.

Giusti, M. M.; L. E. Rodriguez-Saona and R.E. Wrolstad (1999). Spectral characteristics, molar absorptivity and color of pelargonidin derivatives. J. Agric. Food Chem. 47: 46314637. 
Glenn, D.M.; G.J. Puterka; T. Vvonderzwet; R.E. Byer and C. Feldhake (1999). Hydrophobic particle films: a new paradigm for suppression of anthropoid pests and plant diseases. J. Econ. Entomol. 92: 759-771.

Gomez, K.A. and A.A. Gomez (1984). Statistical Procedures for Agricultural Research (2 ed.). John Wiley and Sons, NewYork, 680p.

Hegazi, A.; N.R. Samra; E.E.T. El-Baz; B.M. Khalil and M.S. Gawish (2014). Improving fruit quality of Manfaloty and Wonderfull pomegranates by using bagging and some spray treatments with gibberellic acid, calcium chloride and kaolin. J. Plant Production, Mansoura Univ., Vol. 5 (5): 779-792.

Hudina, M.; F. Stampar; P. Orazem; M.M. Petkovsek and R. Veberic (2012). Phenolic compounds profile carbohydrates and external fruit quality of the 'Concorde' pear (Pyrus communis L.) after bagging. Canad. J. of Plant Sci., 92 (1): 67-75.

Melgarejo, P.; J.J. Martı'nez; F. Herna'ndez; R. Martı'nez-Font; P. Barrows and A. Erez (2004). Kaolin treatment to reduce pomegranate sunburn. Sci. Hortic., 100: 349 353.

Mohamed, M. A.; H. I. M. Ibrahiem and M. O. A. Omar (2014). Selecting the best N, P and K levels for the newly introduced Wounderful pomegranate trees grown under Minia region. World Rural Observations, 6 (4): 2329.

Nicholas, S. (1996). The function and metabolism of ascorbic acid in plants. Ann. Bot. 78: 661669.

Pace, B.; F. Boari; V. Cantore; L. Leo; S. Vanadia; E. De Palma and N. Phillips (2007). Effect of particle film technology on temperature, yield and quality of processing tomato. Acta Hortic. 758, 287-293.

Rico-García, E.; F. Hernández-Hernández; G. M. Soto-Zarazúa and G. Herrera-Ruiz (2009). Two new methods for the estimation of leaf area using digital photography. Int. J. Agric. Biol., 11: 397-400.
Saavedra, Del, R.G.; M.G. Escaff and J. V. Hernandéz (2006). Kaolin effects in processing tomato production in Chile. Acta Hortic., 724: 191-198.

Samra, B.N. and A.M. Shalan (2013). Studies on thinning, bagging and aluminum silicate spraying on yield and quality of Wonderfull pomegranate. J. Plant Production, Mansoura Univ, 4 (2): 219-227.

SAS Institute Inc. (2008). The SAS System for Windows, Version 9.13, SAS Institute Inc., Cary, NC, USA. Singh, Z. and L. Singh.

Shen, J.; L. Wu; H. Liu; B. Zhang; X. Yin; Y. Ge and $\mathrm{K}$. Chen (2014). Bagging treatment influences production of $\mathrm{C} 6$ aldehydes and biosynthesis-related gene expression in Peach fruit skin. Molecules, 19: 1346113472.

Steel, R. G. and J.H. Torrie (1980). Principles and Procedures of Statistics. A Biometrical Approach. 2 nd Edition, McGraw-Hill Book Company. New York, U.S.A. p. 580.

Tora, J. M.; J. Lee; S. E. Spayd and C. F. Scagel (2008). Berry temperature and solar radiation alter acylation, proportion and concentration of anthocyanin in Merlot grapes. Amer. J. Enol. Vitic., 59: 235-247.

Weerakkody, P.; J. Jobling; M.M.V. Infante and G. Rogers (2009). The effect of maturity sunburn and the application of sunscreen on the internal and external qualities of pomegranate fruit grown in Australia. Sci. Hort., 124 (1): 57-61.

Wunsche, N.; L. Lombardini and D.H. Greer (2004). 'Surround' particle film applications: Effects on whole canopy physiology of apple, Acta Hortic., 636: 565- 575.

$\mathrm{Xu}$, H. X.; J.W. Chen and M. Xie (2010). Effect of different light transmittance paper bags on fruit quality and antioxidant capacity in loquat. J. Sci. Food \& Agric., 90: 17831788.

Yazici, K. and L. Kaynak (2005). Effects of kaolin and shading treatment on sunburn on fruit of Hicnazar cultivar of pomegranate (Punica granatum L. cv. Hicnazar). Acta Hortic., 818: 167-174. 


\section{الماذص العرب \\ تمسين جوة ثمار الرملن صف وندفول بلستخدلم التكيي ومعاملات زراعية مختلهة}

محمود عبدللستار، أحمد عبه عيسمسال محمود الثانلى، أحمسعيد العبد

قمم الفلكهة - كلية الزراعة - جلمعة الإسكندرية

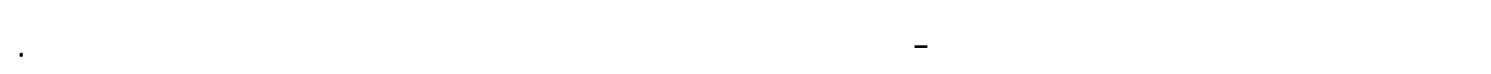

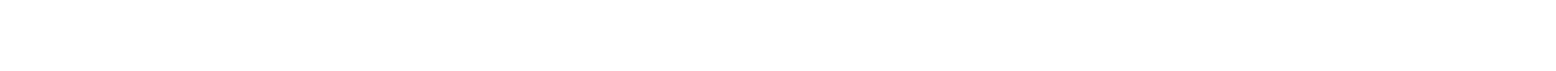




- أن كل المعلملات المختلفة أثرت معنويا على نسبة وعدد الثمار المصابة بلسعة اللثهس، فى حين أن المعلملة

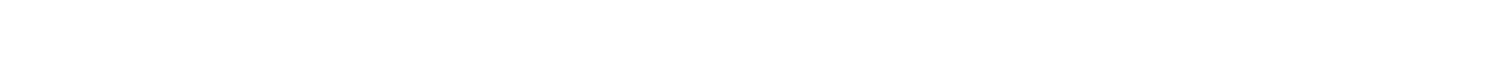
بلسعة اللشهس مقارنة بالكنترول. - معاملة التكييس وش اللسوبر نانو على الثمار فقط أو اللججرة قللت معنويا من حجم مسلحة اللسعة على الثمار.

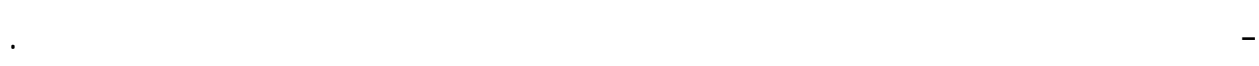
- المعلملة بللسوبر نانو وشا على الثمار فتط كلنت الافضل فل زيادة نسبة المواد الصلبة الذائبة الكلية/ الحموضة.

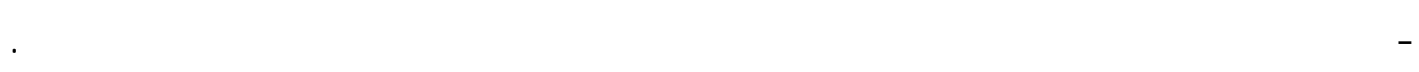

